\title{
Lung Cancer-Related Pneumopericardium
}

\section{Pneumopericárdio Secundário a Cancro do Pulmão}

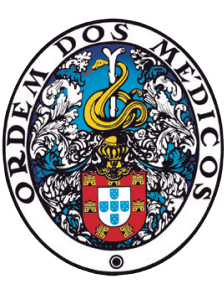

Pedro OLIVEIRA SANTOS $\square^{1}$, João Pedro CALDEIRA ${ }^{1}$

Acta Med Port 2022 Feb;35(2):150-151 - https://doi.org/10.20344/amp.13802

Keywords: Lung Neoplasms; Pneumopericardium; Tomography, Spiral Computed; X-Ray Film

Palavras-chave: Filme para Raios X; Neoplasias do Pulmão; Pneumopericárdio; Tomografia Computadorizada Espiral

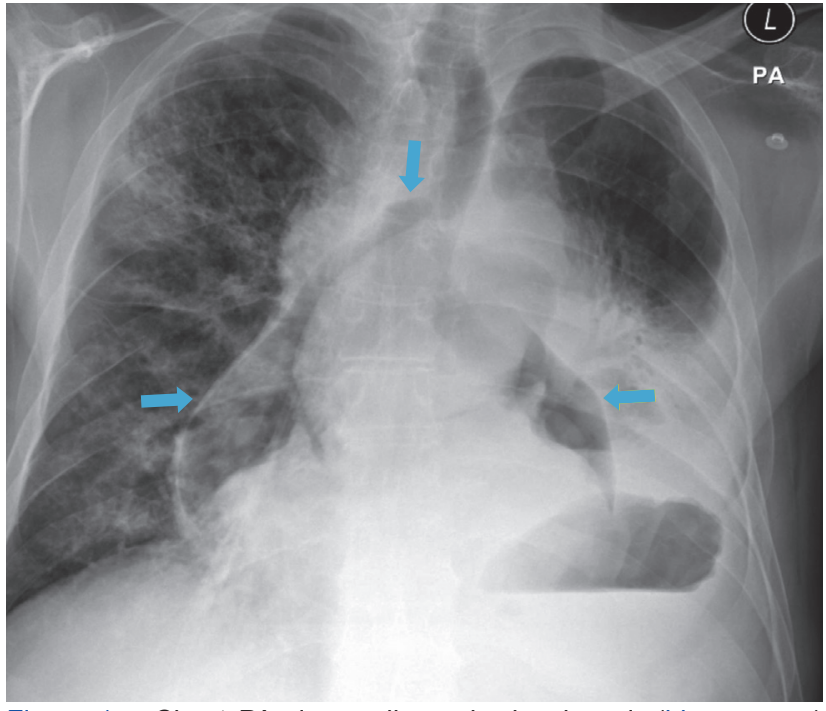

Figure 1 - Chest PA view radiograph showing air (blue arrows) around the heart, the aorta and the main pulmonary artery

A 52-year-old man presented to our hospital with chest pain and shortness of breath. He was being treated with chemotherapy for a peri-hilar, infiltrative squamous cell carcinoma of the left lung with nodal involvement.

The chest radiograph (Fig. 1) revealed air outlining the inner surface of the mediastinal pleura, particularly around the aorta and the main pulmonary artery, consistent with pneumomediastinum. A computed tomography (Fig. 2) confirmed the pneumopericardium diagnosis, associated with a sizeable broncho-pericardial fistula created by the necrotic tumour.

Pneumopericardium consists of air around the mediastinal structures, often extending to the neck, chest wall or even causing pneumothorax..$^{1,2}$ It is a rare and often fatal entity. ${ }^{3,4}$ Although pneumopericardium is commonly associated with blunt trauma or iatrogenic causes (such as invasive procedures or mechanical ventilation), other causes should be considered, such as cancer (particularly esophageal and lung cancer). ${ }^{1,3,4}$

\section{AUTHORS CONTRIBUTION}

POS: Analysis of the clinical file of the patient. Draft of

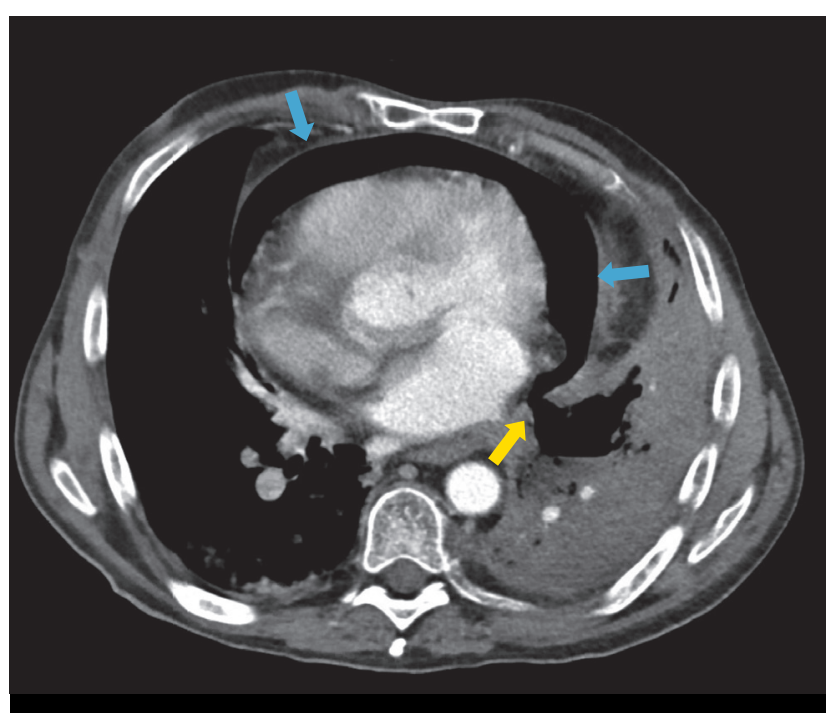

Figure 2 - Axial computed tomography image depicting the pneumopericardium (blue arrows), the broncho-pericardial fistula (yellow arrow) and the necrotic lung tumor

the paper and selection of images.

JPC: Interpretation of medical images. Critical review of the paper and final approval of the manuscript.

\section{PROTECTION OF HUMANS AND ANIMALS}

The authors declare that the procedures were followed according to the regulations established by the Clinical Research and Ethics Committee and to the 2013 Helsinki Declaration of the World Medical Association.

\section{DATA CONFIDENTIALITY}

The authors declare having followed the protocols in use at their working center regarding patients' data publication.

\section{PATIENT CONSENT}

Obtained.

\section{COMPETING INTERESTS}

The authors have declared that no competing interests exist.

1. Serviço de Radiologia. Instituto Português de Oncologia de Lisboa Francisco Gentil. Lisboa. Portugal.

$\triangle$ Autor correspondente: Pedro Oliveira Santos. 63850@ipolisboa.min-saude.pt

Recebido: 27 de março de 2020 - Aceite: 24 de novembro de 2020 - First published: 15 de fevereiro de 2021 - Online issue published: 01 de fevereiro de 2022 Copyright $\odot$ Ordem dos Médicos 2021 


\section{FUNDING SOURCES}

This research received no specific grant from any funding agency in the public, commercial, or not-for-profit sectors.

\section{REFERENCES}

1. Webb WR, Higgins CB. Thoracic imaging - pulmonary and cardiovascular radiology. Philadelphia: Lippincott Williams and Wilkins; 2011.

2. Bejvan SM, Godwin JD. Pneumomediastinum: old signs and new signs. Am J Roentgenol. 1996;166:1041-8.

3. Fernández Isla LE, Fernández Ruíz JS. Neumopericardio en un paciente con carcinoma de pulmón. Semergen. 2017;43:463-5.

4. Hirani S, Velez Martinez CS, Patan S, Kavanaugh M. Cancer-related pneumopericardium: a case report and literature review. Case Rep Oncol. 2020;13:23-8. 